\title{
Analisis Pengaruh Pelayanan Terhadap Anggota Kepuasan KJKS BMT Tumang, Kabupaten Boyolali
}

\author{
${ }^{1}$ Harun Santosa, ${ }^{2}$ Ulul Azmi Mutofa \\ ${ }^{1,2}$ Program Studi Akuntansi, STIE AAS Surakarta, Indonesia \\ *Email korenponden: haruntop@yahoo.com
}

Recieved10-10-2017| Revised 09-11-2017| Accepted 14-11-2017

\begin{abstract}
Jasa Keuangan syariah yang lebih dikenal dengan Baitul Maal Wat-Tamwil (BMT) merupakan lembaga keuangan dalam bentuk koperasi. Penelitian ini bertujuan untuk untuk mengetahui pengaruh reliability, compliance, empathy, reponsivenes terhadap kepuasan anggota KJKS BMT Tumang Kabupaten Boyolali. Teknik penentuan sampel dalam penelitian ini melalui penyebaran kuesioner sebanyak 125 sampel dari anggota KJKS BMT Tumang. Model analisis yang digunakan dalam penelitian ini adalah regresi linier berganda. Dari penelitian ini didapat bahwa reliability, compliance, secara parsial tidak berpengaruh signifikan terhadap variabel kepuasan anggota KJKS BMT Tumang Kabupaten Boyolali, sementara empathy dan reponsivenes secara parsial berpengaruh signifikan terhadap variabel kepuasan anggota KJKS BMT Tumang Kabupaten Boyolali.
\end{abstract}

Kata kunci: Reliability, Compliance, Empathy, Reponsivenes dan Kepuasan anggota.

Saran sitasi: Santosa, H., \& Mutofa, U. (2017). Analisis Pengaruh Pelayanan Terhadap Anggota Kepuasan KJKS BMT Tumang, Kabupaten Boyolali. Jurnal Ilmiah Ekonomi Islam, 3(03), 167-172. doi:http://dx.doi.org/10.29040/jiei.v3i03.112

DOI: http://dx.doi.org/10.29040/jiei.v3i03.112

\section{Pendahuluan}

Lembaga yang menjadi pelopor berdirinya Bank Islam adalah Islammic Developepment Bank (IDB). Munculnya upaya mendirikan lembaga ini di dasarkan atas pemehaman bahwa bunga bank yang ditimbulkan dari transaksi simpan pinjam di bank konvensional adalah riba ( Sadi, 2015).Tumbuh dan berkembangya badan usaha lain yang menerapkan syariah, diantaranya adalah assuransi syariah, transaksi foreign exchange syariah dan perdagangan bursa saham syariah, pegadaian syariah, BPRS serta Koperasi syariah yang lebih dikenal dengan Baitul Maal Wat-Tamwil.

Koperasi simpan pinjam syariah atau Koperasi jasa keuangan syariah disingkat KJKS memiliki dimensi yang berbeda dengan koperasi simpan pinjam konvensional demikian pula jika dibandingkan dengan BMT. Perkembangan ekonomi syariah di Indonesia yang notabene memiliki jumlah penduuk muslim sangat tinggi di sambut oleh pelaku bisnis jasa keuangan dengan mendirikan bank syariah. Koperasi merupakan salah satu badan hukum yang sudah dikenal masyarakat, perkembangan koperasi simpan pinjam menjadi simpan pinjam syariah menjadi salah satu momentum keberhasilan pengembangan ekonomi syariah (Muhammad, 2011).

Pada prinsipnya Koperasi Jasa Keuangan Syariah adalah koperasi Simpan Pinjam Syariah yang kegiatan usahanya meliputi bidang 
pembiayaan, investasi, dan simpanan yang sustemnya sesuai pola bagi hasil (syariah). Lembaga keuangan mikro seperti koperasi yang tahan terhadap guncangan krisis karena berfokus pada sektor mikro seperti masyarakat pedesaan dan usaha kecil dan menengah (UKM). Khususnya Koperasi Jasa Keuangan Syariah Baitul Mal Wat-tamwil Tumang (KJKS BMT Tumang), sebagai salah satu lembaga keuangan mikro yang berasal dari Kabupaten Boyolali yang sampai sekarang berkembang ke Kabupaten Salatiga, Kabupaten Semarang, Kabupaten Sukoharjo dan Kota Surakarta yang selalu menunjukkan kinerja positif, juga masih membutuhkan berbagai pengembangan (Muhammad, 2011).

Sebenarnya antara Koperasi Jasa Keuangan Syariah (KJKS) dan BMT sama saja. Hanya saja ada perbedaan pada lembaganya yaitu pada koperasi syariah hanya terdiri satu lembaga saja, yaitu koperasi yang dijalankan dengan sistem Syariah. Sedangkan pada BMT terdapat 2 (dua) lembaga yaitu diambil dari namanya 'Baitul Maal Wa At Tamwil' yang berarti 'Lembaga Zakat dan Lembaga Keuangan (Syariah)'. Baitul Maal berarti Lembaga Zakat dan At-Tamwil berarti Lembaga Keuangan Syariah (Muhammad, 2011). Sehingga kepuasan pelayanan menjadi prioritas dalam setiap aktivitasnya. Hasil studi empiris Zafar (2012) menunjukkan bahwa kepuasan pelanggan berpengaruh positif signifikan terhadap loyalitas pelanggan. Begitu juga hasil studi yang dilakukan oleh Wibowo (2014); Ramdhani (2011) dan Wijayanti (2009). Hal ini yang menjadi manarik peneliti untuk mengetahui lebih lanjut tentang pengaruh pelayanan terhadap kepuasan.

\section{Kajian Pustaka}

Kotler dan Amstrong (2007) mendefinisikan customer satisfaction is the extent to which a product's perceived performance matches a buyer's expectation. Yang artinya sebagai berikut: kepuasan pelanggan adalah suatu fungsi dari perbedaan yang didapat dari sebuah produk dengan harapan pembelinya cara mengukur kepuasan pelanggan. Setiap perusahaan pasti menetapkan target untuk mencapai setiap tujuannya. Salah satunya dalam pencapaian kepuasan konsumen atau anggota. Selain untuk mengetahui sampai dimana kepuasan konsumennya atau anggotanya, pasti juga ingin menggunakannya untuk bahan evaluasi kedepannya. Menurut Kotler dan keller (2007) mengatakan bahwa kepuasan konsumen adalah perasaan senang atau kecewa seseorang yang muncul setelah membandingkan kinerja (hasil) produk yang dipikirkan terhadap kinerja yang diharapkan Kepuasan konsumen adalah tingkat perasaan konsumen setelah membandingkan antara apa yang dia terima dan harapannya (Husein, 2005). Seorang pelanggan, jika merasa puas dengan nilai yang diberikan oleh produk atau jasa, sangat besar kemungkinannya menjadi pelanggan dalam waktu yang lama.

Menurut Tjiptono (2008), Kulitas pelayanan sebagaimana sebagaimana dirasakan pelanggan dapat diketahui dengan cara membandingkan persepsi pelanggan atas pelayanan yang nyatanyata mereka terima atau perolehan dengan pelayanan yang sesunggunya meraka harapkan atau inginkan. Salah satu model yang dapat digunakan untuk mengetahui kualitas pelayanan dengan model CARTER. Model CARTER dapat digunakan untuk mengukur kualitas jasa dalam lembaga yang menjadikan syariah sebagai dasar organisasinya. Dimensi CARTER jika dijelaskan dalam konsep isalm adalah sebagai berikut:

a. Compliance (pemenuhan konsep sayriah) kemempuan koperasi syariah dalam memenuhi prinsip-prinsip syariah yang diukur dalam menjalanakan prinsip dan hukum islam, tidak ada pembayaran bunga baik tabungan ataupun pinjaman, menerapkan ketentuan layanan produk secara islami, kesempatan mendapatkan pinjaman bebas bunga. Jobs (2007), mengatakan bahwa transaksi pinjaman islam diatur oleh ajaran dari syariah, yang melarang adanya bunga. Bagi perbankan syariah, kepatuhan terhadap ketentuansyariah (syaria compliance) merupakan prasyarat utama beroperasinya bank syariah. 
b. Reliability (keandalan), yaitu kemmpuan perusahaan untiuk memberikan pelayanan sesuai dengan yang dijanjikan secara akurat dan terpercaya. Kinerja harus sesuai dengan harapan nasabahyang berarti ketepatan waktu, pelayanan yang sama untuk semuanasabah tanpa kesalahan, sikap yang simpatik dan dengan akurasi yang tinggi. Sebagai seorang muslim, telah ada contoh teladan yang tentunyabisa dijadikan pedoman dalam menjadikan aktifitas perniagaan/ muamalah. Penelitian

c. Empathy (emati), yaitu memberikan perhatian yang tulus dan bersifat individual atau pribadi yang diberilkan kepada para nasabah dalam berupaya memahami keinginan konsumen. Suatu perusahaan (bank syariah) diharapkan memiliki pengrtian dan perngetahuan tentang nasabah, memahami kebutuhan nasabah, secara spesifik, serta neniliki waktu pengoperasian yang nyaman bagi nasabah.

d. Reponsivenes (daya tangkap) yaitu: suatu kebijakan untuk membantu adn memberikan pelayanan yang cepet (responsif) dan tepat kepada pelanggan dengan penyampian informasi yang jelas dan benar. Islam mengajarkan bahwaa dalam melakukan komitmen disuatu perusahaan (koperasi syariah) harus memberikan pelayana yang baik, sehingga jika perusahaan, (koperasi syariah) tidak bisa menepati, maka resiko yang akan terjadi adalah ditinggalkan para nasabah.

\section{Metode Penelitian}

Metode pengumpulan data dalam penelitian ini menggunakan data primer yaitu data yang berasal dari Anggota atau nasabah KJKS BMT Tumang Kabupaten Boyolali sebagai responden.
Selain itu juga digunakan data sekunder, yaitu merupakan data yang diperoleh dengan proses mengolah data lebih lanjut. Sedangkan teknik pengumpulan data dalam penelitian ini dengan cara Kuesioner. Kuesioner yaitu dengan cara penyebaran angket tertutup berupa daftar pertanyaan mengenai masalah yang akan diteliti yang ditujukan kepada anggota KJKS BMT Tumang Kabupaten Boyolali yang menjadi sampel penelitian. Model analisis yang digunakan dalam penelitian ini adalah regresi linier berganda (Ghozali, 2006), yang digunakan untuk mengetahui pengaruh Reliability, Compliance, Emphaty, Responsiveness terhadap kepuasan anggota KJKS BMT Kabupaten Boyolali.

\section{Hasil Dan Pembahasan}

\subsection{Hasil Penelitian}

Analisis regresi linier berganda digunakan untuk mengetahui tingkat pengaruh dari pengetahuan tentang Reliability, Compliance, Emphaty dan Responsiveness terhadap kepuasan anggota KJKS BMT Kabupaten Boyolali. Berdasarkan data-data yang telah diperoleh melalui kusioner, analisis regresi linier berganda, diperoleh hasil sebagaimana pada Tabel 1.

Dari perhitungan Tabel 1, diperoleh model regresi linier berganda yang secara matematis dapat ditulis sebagai berikut:

$\mathrm{Y}=1,030+-0,005 \mathrm{X}_{1}+0,095 \mathrm{X}_{2}+0,346 \mathrm{X}_{3}+$ $0,507 \mathrm{X}_{4}$

Dalam persamaan regresi di atas dapat diartikan bahwa:

a. Nilai Konstanta sebesar 1,030 artinya apabila nilai variabel independen Reliability $\left(\mathrm{X}_{1}\right)$, Compliance $\left(\mathrm{X}_{2}\right), \quad$ Emphaty $\left(\mathrm{X}_{3}\right)$, Responsiveness $\left(\mathrm{X}_{4}\right)$ bernilai nol maka nilai kepuasan anggota sebesar 1,030

Tabel 1. Uji Signifikansi Parameter Individual

\begin{tabular}{lccc}
\hline \multicolumn{1}{c}{ Model } & Koefisien & t hitung & Sig. \\
\hline Konstan & 1,030 & 0,660 & 0,511 \\
Reliability $\left(\mathrm{X}_{1}\right)$ & $-0,005$ & $-0,067$ & 0,946 \\
Compliance $\left(\mathrm{X}_{2}\right)$ & 0,095 & 1,385 & 0,168 \\
Emphaty $\left(\mathrm{X}_{3}\right)$ & 0,346 & 3,790 & 0,000 \\
Responsiveness $\left(\mathrm{X}_{4}\right)$ & 0,507 & 6,623 & 0,000 \\
\hline
\end{tabular}

Dependen Variabel: Kepuasan Anggota

Keterangan:**signifikan pada level 0,05 
b. Koefisien regresi Reliability $\left(\mathrm{X}_{1}\right)$ sebesar $0,005 \mathrm{X}_{1}$ artinya apabila nilai Reliability $\left(\mathrm{X}_{1}\right)$ meningkat 1 poin maka pergerakan kepuasan anggota akan turun sebesar 0,005 poin.

c. Koefisien regresi Compliance $\left(\mathrm{X}_{2}\right)$ sebesar 0,095 artinya apabila nilai Compliance $\left(\mathrm{X}_{2}\right)$ meningkat 1 poin maka pergerakan kepuasan anggota akan naik sebesar 0,095 poin.

d. Koefisien regresi Emphaty $\left(\mathrm{X}_{3}\right)$ sebesar 0,346 artinya apabila nilai Emphaty $\left(\mathrm{X}_{3}\right)$ meningkat 1 poin maka pergerakan kepuasan anggota akan naik sebesar 0,346 poin

e. Koefisien regresi Responsiveness $\left(\mathrm{X}_{4}\right)$ sebesar 0,507 artinya apabila nilai Responsiveness $\left(\mathrm{X}_{4}\right)$ meningkat 1 poin maka pergerakan kepuasan anggota akan naik sebesar 0,507 poin

Pengujian hipotesis dilakukan untuk menguji pengeruh Reliability, Compliance, Emphaty, Responsiveness terhadap kepuasan anggota KJKS BMT Kabupaten Boyolali menggunakan uji t (uji parsial) adalah sebagai berikut:

1. Reliability mempunyai nilai thitung sebesar 0,067 dengan tingkat signifikansi sebesar 0,946. Karena nilai signifikansi lebih besar dari 0,05 dan nilai $t_{h}(0,067)>t_{t}(-1,979)$ maka $\mathrm{H}_{0}$ diterim. Hal ini menunjukkan bahwa hipotesis satu $\left(\mathrm{H}_{1}\right)$ dalam penelitian ini dapat ditolak, artinya variabel Reliability tidak mempunyai pengaruh negatif dan signifikan terhadap Kepuasan Anggota KJKS BMT Tumang Kabupaten Boyolali.

2. Compliance mempunyai nilai $\mathrm{t}$ hitung sebesar 1,385 dengan tingkat signifikansi sebesar 0,168. Karena nilai signifikansi lebih besar dari 0,05 dan nilai $\mathrm{t}_{\mathrm{h}}(1,385)<\mathrm{t}_{\mathrm{t}}$ $(1,979)$ maka $\mathrm{H}_{0}$ diterima. Hal ini menunjukkan bahwa hipotesis kedua $\left(\mathrm{H}_{2}\right)$ dalam penelitian ini dapat ditolak, yaitu variabel Compliance tidak mempunyai pengaruh positif dan signifikan terhadap Kepuasan Anggota KJKS BMT Tumang Kabupaten Boyolali.

3. Emphaty mempunyai nilai t hitung sebesar 3.790 dengan tingkat signifikansi sebesar
0,000. Karena nilai signifikansi lebih kecil dari 0,05 dan nilai $\mathrm{t}_{\mathrm{h}}(3,790)>\mathrm{t}_{\mathrm{t}}(1,979)$ maka $\mathrm{H}_{0}$ ditolak. Hal ini menunjukkan bahwa hipotesis ketiga $\left(\mathrm{H}_{3}\right)$ dalam penelitian ini dapat diterima, yaitu variabel Emphaty mempunyai pengaruh positif dan signifikan terhadap Kepuasan Anggota KJKS BMT Tumang Kabupaten Boyolali.

4. Responsiveness mempunyai nilai $\mathrm{t}$ hitung sebesar 6,623 dengan tingkat signifikansi sebesar 0,000. Karena nilai signifikansi lebih kecil dari 0,05 dan nilai $t_{h}(9,028)>t_{t}(1,979)$ maka $\mathrm{H}_{0}$ ditolak. Hal menunjukkan bahwa hipotesis keempat $\left(\mathrm{H}_{4}\right)$ dalam penelitian ini dapat diterima, yaitu variabel Responsiveness mempunyai pengaruh positif dan signifikan terhadap Kepuasan Anggota KJKS BMT Tumang Kabupaten Boyolali.

Jadi Secara parsial variabel $\left(\mathrm{X}_{1}\right)$ Reliability Tidak terdapat pengaruh negatif antara Reliability terhadap Kepuasan Anggota KJKS BMT Tumang Kabupaten Boyolali. Variabel $\left(\mathrm{X}_{2}\right)$ compliance dari hasil pengujian penelitan membuktikan tidak terdapat pengaruh positif antar Compliance terhadap Kepuasan Anggota KJKS BMT Tumang Kabupaten Boyolali. Hasil penelitian ini memperkuat penelitian yang dilakukan Wijayanti (2009) dimana Emphaty tidak mempunyai pengaruh yang signifikan terhadap Kepuasan Anggota. Variabel $\left(\mathrm{X}_{3}\right)$ Emphaty membuktikan terdapat pengaruh positif antara Emphaty terhadap Kepuasan Anggota KJKS BMT Tumang Kabupaten Boyolali Hasil penelitian ini memperkuat penelitian yang dilakukan Pardana (2015) dimana Emphaty mempunyai pengaruh yang positif terhadap Kepuasan Anggota. Adapun variabel $\left(\mathrm{X}_{4}\right)$ Responsiveness dari hasil pengujian penelitan membuktikan terdapat pengaruh positif antara Responsiveness terhadap Kepuasan Anggota KJKS BMT Tumang Kabupaten Boyolali Hasil penelitian ini memperkuat penelitian yang dilakukan Pardana (2015) dimana Responsiveness mempunyai pengaruh yang positif terhadap Kepuasan Anggota. 
Jurnal Ilmiah Ekonomi Islam, 3(03), 2017, 167

Tabel 2. Hasil Uji F

\begin{tabular}{lrccc}
\hline \multicolumn{1}{c}{ Model } & Sum of squqres & Df & F hitung & Sig \\
\hline Regression & 392,510 & 4 & 51,132 & 0,000 \\
Residual & 230,290 & 120 & & \\
Total & 622,800 & 124 & & \\
\hline
\end{tabular}

Keterangan: $* *$ signifikan pada $\alpha 0,05$

Tabel 3. Hasil uji koefisien determinasi

\begin{tabular}{cccc}
\hline $\mathrm{R}$ & $\mathrm{R}$ Square & Adjusted R Square & Std.Error of The Estimate \\
\hline $0,794^{\mathrm{a}}$ & 0,630 & 0,618 & 1,38531
\end{tabular}

Sementara Uji F (simultan/menyeluruh) dilakukan dengan tujuan untuk mengetahui seberapa jauh semua variabel independen yang terdiri dari Reliability, Compliance, Emphaty dan Responsiveness secara menyeluruh berpengaruh terhadap variabekependen kepuasan anggota KJKS BMT Kabupaten Boyolali (Y). Adapun hasil perhitungan uji F sebagaimana Tabel 2.

Dari Tabel 2. dapat dilihat bahwa nilai signifikansi adalah sebesar 0,000 dan nilai $\mathrm{F}$ hitung sebesar 47,017. Sebagai dasar pengambilan keputusan adalah tingkat signifykansinya alpa sebesar 5\% $(\sigma=0,05)$. Dasar keputusan yang lain apabila $\mathrm{F}$ hitung $>\mathrm{F}_{\text {tabel }}$ itu menyatakan adanya pengaruh variabel independen terhadap variabel dependen. Dari perhitungan diatas Cdapat dilihat bahwa $\mathrm{F}$ hitung sebesar 51,132 dengan derajat k-1 (4-1 =3) dan derajat penyebut $\mathrm{n}-\mathrm{k}(125-3=122)$ dengan signifikansi $5 \%$ diperoleh $\mathrm{F}$ tabel sebesar 2,45 karena $\mathrm{F}_{\text {hitung }}=51,132>\mathrm{F}_{\text {tabel }}=2,45$ maka model regresi dapat digunakan untuk memprediksi ketepatan kepuasan anggota atau dapat dikatakan bahwa Reliability, Compliance, Emphaty dan Responsiveness secara simultan berpengaruh terhadap kepuasan anggota, sehingga model dapat digunakan dalam penelitian ini. Sehingga Hasil penelitian menunjukkan adanya pengaruh secara bersama-sama dari variabel bebas yaitu Reliability, Compliance, Emphaty, Responsiveness terhadap variabel terikat Kepuasan Anggota. Hasil penelitian ini sejalan dengan temuan penelitian Wibowo (2014).

Hasil perhitungan Uji Ketepatan Model atau penghitungan koefisien determinasi dapat dilihat dalam Tabel 3.

Nilai koefisien determinasi yang sudah disesuaikan (adjusted $\mathrm{R}^{2}$ ) sebesar 0,618 atinya $61,8 \%$ variabel dependen yaitu Kepuasan Anggota dapat dijelaskan oleh variabel-variabel independen seperti Reliability, Compliance, Emphaty, Responsiveness dan sisanya 38,2 \% dijelaskan oleh variabel lain diluar variabel yang digunakan. Nilai adjusted $\mathrm{R}^{2}$ untuk Kepuasan Anggota yang besar akan membuat model regresi semakin tepat dalam memprediksi Kepuasan Anggota.

\subsection{Pembahasan}

Hasil penelitian menunjukkan adanya pengaruh secara bersama-sama dari variabel bebas yaitu Reliability, Compliance, Emphaty, Responsiveness terhadap variabel terikat Kepuasan Anggota. Hasil penelitian ini sejalan dengan temuan penelitian Wibowo (2014) dan Zafar (2012).

Secara parsial Reliability tidak terdapat pengaruh negatif terhadap Kepuasan Anggota KJKS BMT Tumang Kabupaten Boyolali, Compliance dari hasil penelitan ini membuktikan tidak terdapat pengaruh positif antar Compliance terhadap Kepuasan Anggota KJKS BMT Tumang Kabupaten Boyolali, hasil penelitian ini memperkuat penelitian yang dilakukan Wijayanti (2009) dimana Compliance tidak mempunyai pengaruh yang signifikan terhadap kepuasan anggota. Sedangkan Emphaty dari hasil pengujian penelitan membuktikan terdapat pengaruh positif antara Emphaty terhadap Kepuasan Anggota KJKS BMT Tumang Kabupaten Boyolali Hasil penelitian ini memperkuat penelitian yang dilakukan Pardana (2015) dimana Emphaty mempunyai pengaruh yang positif terhadap Kepuasan Anggota. Responsiveness dalam penelitan ini membuktikan terdapat pengaruh positif 
terhadap Kepuasan Anggota KJKS BMT Tumang Kabupaten Boyolali, hasil penelitian ini memperkuat penelitian yang dilakukan Pardana (2015) dimana Responsiveness mempunyai pengaruh yang positif terhadap Kepuasan Anggota.

\section{Kesimpulan}

Berdasarkan hasil analisis dapat disimpulkan bahwa ; Reliability Tidak terdapat pengaruh negatif terhadap Kepuasan Anggota KJKS BMT Tumang Kabupaten Boyolali. Compliance tidak terdapat pengaruh positif terhadap Kepuasan Anggota KJKS BMT Tumang Kabupaten Boyolali. Emphaty mempunyai pengaruh signifikan positif terhadap Kepuasan Anggota KJKS BMT Tumang Kabupaten Boyolali Responsiveness mempunyai pengaruh signifikan positif terhadap Kepuasan Anggota KJKS BMT Tumang Kabupaten Boyolali Reliability, Compliance, Emphaty dan Responsiveness secara bersama-sama berpengaruh terhadap Kepuasan Anggota KJKS BMT Tumang Kabupaten Boyolali

\section{Ucapan Terima Kasih}

Penulis ingin mengucapkan terimakasih kepada STIE AAS Surakarta yang telah mendukung selesainya penelitian ini.

\section{Daftar Pustaka}

Ghozali, I. (2006). Aplikasi Analisis Multivariate dengan Program SPSS. Semarang: Badan Penerbit Undip. Semarang

Husein, Umar, (2005). Riset Sumber Daya Manusia dalam Organisasi. Jakarta: PT Gramedia Pustaka Utama

Jobs, A. (2007). The Economic of Islamic Finance and Securitization. Forthcoming in The Journal of Structured Finance Vol.12 (1)
Kotler, P dan Keller, (2009). Manajemen Pemasaran. Jakarta:PT Indeks.

Kotler, Philip dan Amstrong Gary,( 2007). Prinsip-prinsip Pemasaran. Jakarta: Erlangga

Muhammad, (2011). Manajemen Bank Syariah. Yogyakarta: UPP STIM YKPN Yogyakarta

Pardana, S.R. (2015). Analisis Pengaruh kualitas Pelayanan terhadap kepuasan nasabah PT BPR Dana Mulya Surakarta. Jurnal Akuntansi dan Pajak.Vol.15 (2):106117

Ramdhani, M.A. (2011). The Infuence of Service Quality Toward Customer Satisfaction Of Islamic. Journal of Basic and Aplied Sciences Australian. Vol.5 (9): 1099-1104

Sadi, (2015). Perbankan Syariah. Yogyakarta: Citra Intrans Selaras

Tjiptono, F. (2008). Strategi Pemasaran, edisi 3.Yogyakarta: Andi

Wibowo, M. (2014). Perilaku Konsumen Syariah di KJKS/BMT Tumang Kabupaten Boyolali. Jurnal Inovasi dan Kewirausahaan.Vol.3(2): 83-96

Wijayanti, RW. (2009). Pengaruh Bauran Pemasaran Jasa terhadap Loyalitas Anggota pada KJKS BMT Bina Ummat Sejahtera Lasem. Jurnal Analisis Manajemen. Vol.3(2):129- 147

Zafar, Mohsin and Zafar, Sana and Asif, Aasia and Hunjra, Ahmed Imran Imran and Ahmad, H. Mushtaq, (2012). Service Quality, Customer Satisfaction and Loyalty: An Empirical Analysis of Banking Sector in Pakistan (August 16, 2012). Information Management and Business Review, Vol. 4, No. 3, pp. 159-167, Apr 2012. Available at SSRN: https://ssrn.com/abstract=2130359 